\title{
PROTECTION AGAINST LABOR TROUBLES
}

\author{
THE CAMPAIGN OF THE ASSOCIATION DE L'INDUSTRIE \\ FRANÇAISE FOR ECONOMIC STABILITY AND SOCIAL \\ PEACE DURING THE GREAT DEPRESSION, 1880-96
}

By introducing an economic cycle of a new sort in Europe the Great Depression of 1873-96 encouraged the alignment of iron and textile industrialists' interests with those of the great growers and livestock raisers. The French version, perhaps best labelled the alliance of cotton and wheat, is the concern here, for since profits and sales for both agriculture and industry traced parallel curves, for the first time in French history, representatives of these interests could unite and press the new republican leadership for common relief against depression and intensifying foreign competition. They were also impelled to unite in the face of the growing militancy of the new working class emerging in the provinces. Their spokesmen of the Association de l'Industrie Française and the associated Société des Agriculteurs addressed themselves to the new incarnation of the social question by offering protective tariffs - and protected jobs and pay checks to workers striking more frequently and organizing more solidly than ever before. Their slogan was "the protection of national labor". Having no reforms to offer, the Opportunist republicans and their ex-monarchist allies offered the emergent industrial working class safe incomes and economic nationalism.

In the aftermath of the failure of the Empire, in the period of the Great Depression - coinciding political and economic challenges - France's new conservative republican ruling class completed its amalgamation. The French bourgeoisie had tolerated Imperial rule because they could not, they dared not, rule in their own name. ${ }^{1}$ But with the defeat of Napoleon III, and the failure of the monarchists to create a government, bourgeois republicans had to shoulder the task of creating a stable political order which encased and appeased the important sectors of the society. Just the Opportunists' preliminary task of unifying the bourgeoisie was difficult;

${ }^{1}$ Marx's Eighteenth Brumaire of Louis Bonaparte is the most famous attempt to address why and how this was so. 
however, with the large growers they fashioned a socio-political governing bloc in the difficult years of the depression.

At the same time the new provincial working class was also coming to class-consciousness. The coming to awareness of each class was mirrored in the politics of the other. By means of an examination of the struggle over the social meaning of the protective tariffs passed in the 1880's and 1892 I shall try to illuminate the complexities, the false steps, the accommodations and the successes of these parallel and mutually conditioning processes of coming of age. For in the microcosm of the tariff debates in the Chamber, at the hearings of enquêtes, in electoral campaigns, and in the press struggles to sway workers' sentiments in support of protectionism were joined the more fundamental issues of class collaboration or class struggle, economic benefits or political reforms, nationalism or internationalism, economic growth or job protection.

This reconsideration of the early history of the Third Republic will seek not so much to refute the brilliant analysis of Third Republic France as a stalemated society offered by Stanley Hoffmann some twenty years ago, ${ }^{2}$ as to transcend it. Doubtless, as Michael Crozier argued in support of Hoffmann, there grew up in France from the late nineteenth century on a société bloquée; certainly, as both men agreed, the working class was frozen out of public life. ${ }^{3}$ However, this essay will trace the origins of French immobilisme not to the cumulative effects of positions acquises, as Hoffmann believed, nor to bureaucratic rigidities as Crozier views it, but rather to the consequences of the deliberate efforts of Opportunist republicans and ex-monarchists to craft a conservative coalition to defend rank, wealth and aristocratic family heritage at a major turning-point in the history of the society. For what made that conjuncture so frought with danger for those who possessed and those who would lead was the simultaneous convergence of two threats to their power.

The first arose from the long-term depression which, having darkened economic life throughout the 1880 's, worsened at the start of the new decade, compounding the stresses caused by already sinking profits and ruinous foreign competition. The second, which contemporaries dubbed euphemistically the social question, emerged in its modern form of organized and militant industrial workers pressing for immediate economic demands and long-term social transformations which their depressionstruck employers could not meet. The new industrial working class of the

2 S. Hoffmann, "Paradoxes of the French Political Community", in: In Search of France. ed. by id. et al. (New York, 1963).

${ }^{3}$ M. Crozier, La Société bloquée (Paris, 1970). 
provinces was not numerous, but it was powerful enough in textiles, metal working and mining to make employers dread their growing militancy and seek remedies against it. A corollary of worker awakening in the depression years was the continuing flight from the land and the re-kindling of peasant radicalism in the South and Center.

The Hoffmann-Crozier thesis tells us nothing of the role of either depression or socio-economic pressure from below in the formation of the republican order. It defines political power in France negatively: as that which remains of state authority after the interest groups have staked their claims, rather than as the possession of a newly formed bloc dedicated to creating a conservative Republic. ${ }^{4}$ It does not take into account the social workings of the depression.

Between 1873 and 1896 France, as other developed nations of Europe, ${ }^{5}$ suffered downturns of major indices of agricultural and industrial prices, interest rates and commerce. ${ }^{6}$ Prices hit peaks in 1880 and 1890 , just before precipitous downward slides which bottomed out in 1887 and 1896, respectively. ${ }^{7}$ At the same time labor militancy shot up. ${ }^{8}$ After the greater opening to world markets by Imperial fiat, and despite the industrial boom during the Empire, a return to protectionism was the main national economic

${ }^{4}$ Finally, it tends to depict France and the maladies of French society in the late nineteenth-century as unique. It eschews a comparative perspective. Neither depression nor an awakening working class and peasantry were unique to late-nineteenth century France. Nor was neo-conservative coalition building needed only in France; trasformismo in Italy and Sammlungspolitik in Germany represented parallel efforts to rule new states in new ways. This point deserves greater attention than can be devoted to it here. ${ }^{5}$ H. Rosenberg, Grosse Depression und Bismarckzeit. Wirtschaftsablauf, Gesellschaft und Politik in Mitteleuropa (Berlin, 1967); F. Caron and J. Bouvier, "Les Indices majeurs", in: Histoire économique et sociale de la France (Paris, 1970-82), IV/1; J. Bouvier, "Mouvement ouvrier et conjonctures économiques", in: Le Mouvement Social, No 48 (1964); M. Lévy-Leboyer, "L'Héritage de Simiand", in: Revue Historique, CCXLIII (1970); id., "La Croissance économique en France au XIXe siècle: résultats préliminaires", in: Annales, Economies Sociétés Civilisations, XXIII (1968); F. Crouzet, "Essai de construction d'un indice annuel de la production industrielle française au XIXe siècle", ibid., XXV (1970); J. Lescure, Des Crises générales et périodiques de surproduction, 3rd ed. (Paris, 1923).

6 W. A. Lewis, Growth and Fluctuation, 1870-1913 (London, 1978), pp. 17-68, esp. $47-50$.

7 Caron and Bouvier, "Les Indices majeurs", loc. cit.

${ }^{8}$ Bouvier, "Mouvement ouvrier et conjonctures économiques", loc. cit.; E. Shorter and Ch. Tilly, Strikes in France 1830-1968 (Cambridge, 1974); M. Perrot, Les Ouvriers en grève, France 1871-1890 (2 vols; Paris, The Hague, 1974); J. Julliard, "Théories syndicaliste révolutionnaire et pratique gréviste", in: Le Mouvement Social, No 65 (1968); J. Néré, "La Crise industrielle de 1882 et le mouvement boulangiste" (mimeographed dissertation, Paris, 1959); id., Le Boulangisme et la presse (Paris, 1964). 
demand French industrialists made on the new Republic. ${ }^{y}$ Manufacturers in iron, shipbuilders, owners of coal mines, and textiles other than silk had not conquered the world market. And from the 'eighties onwards the big growers of wheat, sugar beets and cattle suffered from the hardships imposed by declining world prices for their products. The men who dominated the Republic after the defeat of the Imperial regime offered them no relief. The convergence of the periodicity of agricultural and industrial prices for the first time during the Great Depression permitted the leaders of the two strata to explore common economic defense. ${ }^{16}$ But more was at

9 Actually, they had already raised this demand in the last days of the Empire, and frequently their workers - even while striking against them - added their own maledictions against free trade in common manifestations of protest. This part of the story of class collaboration around protectionism is too long and complex to discuss here. See my forthcoming The Alliance of Iron and Wheat: Origins of the New Conservatism of the Third Republic, 1860-1914, ch. I. See also C. Fohlen, "Crise textile et troubles sociaux: Le Nord à la fin du Second Empire", in: Revue du Nord, XXXV (1953); id., L'Industrie textile au temps du Second Empire (Paris, 1965); Motte-Bossuet et al., Rapport sur l'émeute du 16 mars 1867 à Roubaix à M. Masson, Préfet du Nord à Lille (n.p.,n.d.), 4 pp.; F. L'Huillier, La Lutte ouvrière à la fin du Second Empire [Cahiers des Annales, No 12] (Paris, 1957); S. Elwitt, "Politics and Social Class in the Loire: The Triumph of the Republican Order, 1869-1873", in: French Historical Studies, VI (1969); P. Léon, "Les Grèves de 1867-1870 dans le département de l'Isère", in: Revue d'Histoire Moderne et Contemporaine, I (1954); R. P. Baker, "A Regional Study of Working-Class Organization in France: Socialism in the Nord, 1870-1924" (Stanford University Ph.D., 1967; University Microfilms, Ann Arbor, Michigan), p. 21. The interesting new work of W. Reddy, The Rise of Market Culture: The Textile Trade and French Society, 1750-1900 (Cambridge, Paris, 1984), nuances the picture of early class-consciousness in the Nord by focusing on the non-economic issues in the lives of the workers. Emile Aubry stands out as an especially astute Northern labor leader who tried to keep the organized textile workers in Rouen from the protectionist temptation: E. Aubry, "Opinion de la Fédération ouvrière de l'arrondissement de Rouen sur la protestation des industriels de la circonscription contre le traité de commerce", in: Journal des Economistes, Third Series, XVI (1869). Although Aubry spoke for the feared International in Rouen, and although its representatives were active in the strike movement of Alsace, the evidence is slim for its agitational successes in the late Empire's labor troubles (Fohlen, L'Industrie textile, p. 436), or indeed in the Paris Commune. But it is also a datum of historical consciousness that government officials and owners charged it with great influence at the time, banning it in France and harrying its members. One contribution of my study, hopefully, shall be to remind us of the importance of initiatives which failed, of actions undertaken from misdirected motives, of misunderstood motives, and of misanalyzed situations. I wish to combat a naive Hegelian teleology which sometimes influences the work of both Marxist and non-Marxist historians alike.

10 E. Labrousse, "A livre ouvert sur les élans et les vicissitudes des croissances", in: Histoire économique et sociale de la France, op. cit., IIU/2; S. Elwitt, The Making of the Third Republic: Class and politics in France, 1868-1884 (Baton Rouge, 1975). The first important broker between often artistocratic growers and often republican industrialists was Augustin Pouyer-Quertier. Most recently on Pouyer-Quertier see J.-P. Chaline, Les Bourgeois de Rouen (Paris, 1982). What better protagonist of a new ruling-class unity of 
stake in the 1880's and 1890 's than a case of upwardly mobile provincial bourgeois politicians uniting representatives of vested economic interests in depressed times around the revival of neo-mercantilist commercial legislation. As this kind of business cycle was new, so were the interest affinities it permitted. The new Republic was untried, or rather not yet shaped socially.

And the provincial industrial workers, who in the course of the depression became increasingly conscious of how their needs and interests differed from those of their employers, were also a new breed. No longer 1848 social republicans, nor bearers of the traditions of the Paris Commune, they comprised the growing levies of modern socialism and revolutionary syndicalism. But even before they posed any serious threat to the political stability of the Third Republic, their largely economic demands in the years of declining prices, diminishing profits and rising wages had a profound political impact on their employers.

For between 1883 and 1899 real wages rose faster than productivity. One estimate puts the increase at approximately 20 per cent. " At least two factors account for the improvements in the material life of the French workers on whom we have statistics. First, the period of amelioration coincided with an accelerating rate of industrial strikes, manifesting the growing social and political militancy of workers. Thus French workers fought successfully to improve their lives by means of the strike, or at least they fought against employers' attempts to depress wages or worsen work conditions in bad times. ${ }^{12}$ Second, the fall in prices improved the purchasing

interest might serious economic leaders want: a self-made man under the Empire, briefly a supporter of Boulanger, Pouyer-Quertier crafted the tariff agitation for republicans like Ferry and Méline to carry on, but married off one daughter to a Count, the other to a Marquis. Elected as a republican Senator in 1876, nevertheless, he was widely identified as a "legitimist".

11 On the data see Lewis, Growth and Fluctuations, op. cit., pp. 94-111, who bases his calculations on E. H. Ph. Brown, with M.H. Browne, A Century of Pay (London, 1968); M. Perrot, "Les Classes populaires urbaines", in: Histoire économique et sociale de la France, IV/1. The improvement of the lives of European workers in the late nineteenth century was one source of the intellectual crisis of European socialism in that epoch. Eduard Bernstein, Rosa Luxemburg and V. I. Lenin each in his/her way realized that current Marxist orthodoxy was unsuited to explain this new reality. The theories of imperialism of Luxemburg and Lenin were in large part aimed at accounting for this violation of the immiseration tendency articulated by Marx. Bernstein called for a re-thinking of Marxist theory because he extrapolated what he believed to be a secular trend of improved conditions for workers.

${ }_{12}$ Strikes after 1899 to 1914 were more frequent and in many ways more militant. But by the turn of the century industrialists had ceased to be as disconcerted by what in the 'eighties and 'nineties was a relatively unexpected style of worker economic resistance. Moreover, in the new century industrialists' organizations were stronger and they themselves had grown more sophisticated about the social question qua wage problem. Most 
power of the workers' households - at least until the effect of the tariffs on their cost of living made itself felt.

Owners of textile mills, iron manufacturers and mine operators struggled desperately with the costs of raw materials, foreign competitors and their own workers' demands in order to keep their firms afloat and to protect the family patrimony. Throughout the Great Depression their dilemma persisted: foreign competition and workers' pressures compelled increased capital investment. This the treatened industrialists were prepared to do. However, the retained profits to pay for new investments were shrinking in the same depressed decades, as were the markets which any improved productivity presupposed. Herein lay the attraction of a protectionist tariff policy: it promised a shield against both external commercial pressures and internal social ones.

Not that French entrepreneurs of the nineteenth century lacked initiative or foresight. As prices declined, many resourceful businessmen looked for ways to achieve economies and for means of rationalizing their operations. ${ }^{13}$ In the late 'seventies and early 'eighties, for example, many manufacturers - especially the cotton-thread and cloth producers of the Nord - invested heavily in modern equipment. ${ }^{14}$ They also pressed their workers for both greater production and increased productivity, as they had done during the business recession of the last years of the Empire. And as in the late 1860 's, this renewed industrialists' assertiveness in the 1880's and 1890 's brought them into frequent and repeated confrontation with their workers. It was this struggle over who was to bear the greatest costs of the depression which ignited the first national struggle between the working class and the increasingly class-conscious industrialists. ${ }^{15}$

important, economic recovery made them less a hostage to their employees. In the decade and a half after 1899 real wages rose more slowly than productivity. Cf. Lewis, Growth and Fluctuations, p. 107; F. Caron, An Economic History of Modern France (New York, 1979), pp. 144, 154; P. Léon, "Le Dynamisme industriel", in: Histoire économique et sociale de la France, III/2, discusses the divisions of opinion in the important literature.

${ }_{13}$ See R. Kuisel's excellent summary of the backwardness debate in his Capitalism and the State in Modern France: Renovation and Economic Management in the Twentieth Century (Cambridge, 1981), ch. I; J. Lambert, Quelques familles du patronat textile de Lille-Armentières (1789-1914). Thèse de doctorat (Lille, 1954), p. 488; M. J. Rust, "Business and Politics in the Third Republic: The Comite des Forges and the French Steel Industry, 1896-1914” (Princeton thesis, 1973; University Microfilms, 1974), pp. 18-19.

${ }_{14}$ M. Smith, Tariff Reform in France, 1860-1900: The Politics of Economic Interests (Ithaca, London, 1980), pp. 132-40.

is Tilly and Shorter, Strikes in France, op. cit., pp. 74-75, 307. The political and economic leaders of other lands also struggled with the social consequences of the world- 
While Jules Méline began to find his way around the corridors of power in the Chamber, his chief backers, the cotton manufacturers of the Vosges, met at the City Hall of his native Remiremont, late in March 1879, to discuss what common action was possible to reverse the serious depression in cotton-goods prices. After some deliberation, they decided that one course of action to avoid was to deal with the economic crisis by reducing wages. They realized, according to the Prefect's report of the meeting, that such a course would only exaggerate the overproduction and underconsumption which was fuelling the decline in sales. After all, their workers, they agreed, were important consumers of their products. ${ }^{16}$

The industrialists of the Nord, who also shared the notion that economic crises originated in the combined effects of overproduction and underconsumption, faced the added worry of an especially explosive workforce. That same March the textile manufacturers of Armentières sent a delegation of their foremen and managers to the Prefect, Paul Cambon, to gain his influence in Paris for higher duties. The industrialists' representatives argued that - in Armentières, at least - just a wage reduction was enough to put the workers in this mill town "into motion", and although they were hard to arouse, "once in motion, they were difficult to stop". For their part, the owners would of course warehouse their surplus production, but they urged Cambon to press their case for immediate tariff protection. ${ }^{17}$

The explosion of labor militancy around the turn of the decade was not restricted to Armentières, or even to the Nord. In the mid 1870's the annual number of strikes on the average was approximately the same as in the early 1840 's. From 1877 onwards the frequency and numbers of workers involved

wide price deflation. Ch. Kindleberger, The Economic Response: Comparative Studies in Trade, Finance, and Growth (Cambridge, Mass., London, 1978), ch. III: "The Rise of Free Trade in Western Europe, 1820-1875". Lands in the midpassage of industrialization, nations moving from largely agrarian social relations towards industrial maturity and therefore towards the social conflicts of newly industrializing societies - sought in protective tariffs a weapon of counter-cyclical social protectionism. In 1879 the German Empire began a series of tariff increases which culminated in 1902 with the passage of the Bülow tariff. Italy and Austria-Hungary followed suit. Even the United States - at that moment experiencing both unprecedented industrial conflict and Populist disaffectionpassed the strongly protectionist McKinley Tariff in 1890.

${ }_{16}$ Prefect of Vosges, communication of 24 March 1879, Archives Nationales F 124655 , cited in Perrot, Les Ouvriers en grève, op. cit., I, pp. 152-53. See the excellent book by M. Bleaney, Underconsumption Theories: A Historical and Critical Analysis (New York, 1976), pp. 9-21, and especially the section on Sismondi, pp. 62-79.

17 Prefect of Nord, Archives Nationales F 124655 . The cotton spinners of the Nord held something on the order of a half year's unsold production of finished yarn worth two million francs. Cf. F. Caron, "Dynamismes et freinages de la croissance industrielle", in: Histoire économique et sociale de la France, IV/1. 
in industrial conflicts shot up. ${ }^{18}$ Contemporaries were amazed by the new rebelliousness. ${ }^{19}$ Workers were striking more often and with more formal organization as the 1870 's gave way to the 1880 's. They did so because of disputes centered largely on issues of pay, hours and work rules. ${ }^{20}$

The industries most crippled by the price plunge of the turn of the decade were also attacked in the new surge of labor militancy. Leading firms in these areas of production comprised the core of the Association de l'Industrie Française. ${ }^{21}$ In many instances owners personally suffered the animosity of their workers in the course of labor actions and often perceived the demands of their workers as threats to the livelihoods of their families. ${ }^{22}$ And it was also in centers of AIF-related industries that owners tried to persuade their restive workpeople to make common cause against the policy of commercial free trade. The AIF orchestrated a national campaign of rallies and petitions. ${ }^{23}$ Many contemporary social conservatives saw

18 Tilly and Shorter, Strikes in France, p. 47; Perrot, Les Ouvriers en grève, 1, pp. 89-90. 19 Ibid.

20 Perrot, Les Ouvriers en grève, I, p. 406; Tilly and Shorter, Strikes in France, p. 342 , specifically deny the importance usually ascribed to wage disputes in the occurrence of nineteenth-century industrial disputes. They see wage demands as "merely a mobilizing device, not a real issue". The economics of the question, I think, tends to support my view.

21 See the list of members, their firms and officers of the AIF in L'Industrie Française, 21 March 1878, pp. 89-90 (reprinted in Smith, Tariff Reform, op. cit., pp. 245ff.), and for the members in 1893 see Le Travail National. 18-23 June 1893.

22 Consider these examples of strikes in firms owned by important members of the AIF. In 1880 the Roubaix weaving firm of Delathe père et fils was struck twice. Mr Julien LeBlan, President of the Lille chamber of commerce, a member of the Executive Committee of the AIF, and manufacturer of linen thread in Lille, in 1882 had twice (1030 October and 6 November) personally to confront workers on strike over pay cuts he had initiated. Even the reputedly docile workers of the Vosges resisted their employers' attempts to make them pay for the business crisis. Just before Christmas 1882 in SaintDié one hundred and sixty workers employed in the weaving firm of Dietsch frères, also members of the AIF, walked off to protest alterations in the shop rules. In 1882 important strikes shook Le Creusot, where Henri Schneider, another AIF Executive Committee member, ruled, and AIF-represented shops in the iron-working regions of Saint-Etienne, Grenoble, Vienne; the coal mines of Carmaux were struck as well. That fall labor troubles broke into violence at the Blanzy coal mines in Monceau-les-Mines. Grèves en France, Archives Nationales F 125749.

23 Early in 1879 in Lille, AIF member Gustave Dubar, the linen manufacturer, had his foremen and managers gather workers' signatures on a protectionist petition. Claiming to have assembled thirty thousand names, they presented the document to President Jules Grévy in May. In Amiens the AIF militants also gathered the signatures of their workers and held public meetings as well to promote protectionism. Nicolas Claude, Méline's mentor in the Vosges, organized similar efforts in the textile-mill towns of the Vosges valleys. Meetings between workers and officials, petition campaigns and rallies blossomed all over Normandy. At Rouen yet another large protectionist demonstration collected thousands of workers' names on anti-freetrade petitions, which in due course 
such tactics as playing with fire: mobilizing the workers was dangerous business. ${ }^{24}$

But in this moment of economic crisis the industrialists could do little to improve the wages of their workers. On the contrary, many felt forced to reduce them in various ways. That made the ideology of "National Labor" - the name of the protectionist newspaper - very tempting: if only the owners and their workers could close ranks and, enfolded in the flag of $l a$ patrie, confront the foreign economic invaders, as, united, they had confronted the Prussian invaders. The first issue of Le Travail National voiced the industrialists' intentions clearly: they sought no conflict with their workers.

Our guiding principle is the solidarity of patron and worker. We reject the categories of "capital" and of "labor", for the patron, like the worker, also labors. Rather, we propose solidarity of all French workers before the threat of foreign competition. ${ }^{25}$

In the early 'eighties a relatively disorganized working class, lacking developed class-consciousness, might be expected to co-operate with their employers. Moreover, the provincial industrial bourgeoisie - still unsure of its strengths and place in French society, nor that of its employees - had good reason to envision themselves arm and arm with their workers, on the order of the artisan shop writ large and run in paternalistic fashion. ${ }^{26}$

Even the economic discourse of their spokesmen promoted the ideology of industrial harmony. When in early February 1881 Méline, as reporter for the tariff commission of the Chamber, presented the draft tariff law which

were presented by AIF stalwarts Lucien Dautresme and Richard Waddington, at the head of a delegation of foremen, to William Waddington, brother to Richard, and Premier.

24 An alarmed contributor to the resolutely free-trade Economiste Français voiced the fears of many of the well-off when he wrote of the protectionist rallies that the agitation was going well beyond the usual speech-making and passing around of petitions: "they were trying to unite with the workers [by telling them] that they [were] going to starve, and that it [was] the fault of the treaties of commerce." Dufrenoy, "La Dernière manifestation protectionniste", in: L'Economiste Français, 10 May 1879. The references and data of the last two paragraphs I owe to Michael Smith's excellent account of protariff agitation. Tariff Reform, p. 163. In the sense of strengthening or weakening pressure-group politics his judgment, "for all the drama and notoriety of such rallies, they played a relatively minor role in the protectionist campaign", is surely accurate. But this telis us little about their role in the larger struggle for social appeasement and class collaboration rather than conflict.

${ }^{25}$ Le Travail National, 6 July 1884 , p. 2.

${ }^{26}$ Cf. P. Stearns's still valuable study of the extent of harmony and paternalism in French industry in the earlier part of the century, Paths to Authority: The Middle Class and the Industrial Labor Force in France, 1820-48 (Urbana, 1978). 
the protectionists had so strenuously promoted, he claimed in his speech introducing the projet de loi that, in the often narrow and detailed discussions of duties on this or that item, he had held tightly to the idea that to spur the accumulation of capital - to increase profits in essence - would benefit workers and capitalists alike. ${ }^{27}$ Méline was proposing, in effect, that perhaps industrial tariffs might be raised high enough to permit sufficiently ample recovery of sales and profits to grant some of the workers' economic demands. He wooed the representatives of the growers in the Chamber, while keeping peace with his industrialist friends, by endorsing the extension of protection to agricultural products to stimulate revival of flagging rural purchasing power. It is likely that the deputies were more smitten by his less abstract arguments about buttressing domestic cotton-thread, pigiron and beef prices which followed the disquisition on economic philosophy. The tariff, as we know, passed.

The tariff act of 1881 was the first approximation at fulfilling the protectionists' commercial and, as we have seen, social hopes - albeit, to many industrialists, a disappointingly inadequate first effort. ${ }^{28}$ The pages of $L e$ Travail National continued to carry their lamentations and expressions of need. Soon after the freetraders, suffering neither from the same commercial nor labor worries, managed to get additional treaties of commerce negotiated..$^{29}$

The continuation of the commercial crisis and of the labor pressure ${ }^{30}$ spurred the Opportunist majority in the Chamber to ponder what additional actions might be taken. It is in the context of the growing labor conflicts of the depression that we should understand the passage of the 1884 syndicat law, a measure permitting workers to form legal trade unions. Despite the opposition of many socialist leaders, who saw Waldeck-

27 Journal Officiel, Chambre des Députés, Débats, 3 February 1880, pp. 1202-03.

28 Smith, Tariff Reform, pp. 180ff.

29 Ibid., pp. $151 \mathrm{ff}$.

30 Although there was a clear upsurge of strike activity in the years $1880-82$, Tilly and Shorter, Strikes in France, pp. 110-12, do not include that peak in their survey of strike waves. They discuss the wave of $1869-70$, which they characterize as "still part of the artisanal pattern", and then go on to the industrial conflicts of 1893 ("near the front end of the long transition from artisanal to mechanized production"). They are right about the industrial transformation going on in that era, but they tend to discount the connection of business-cycle fluctuations with strike activity. They discount, as well, workers' assertions that wages were the overwhelming issue in the majority of strikes - as well as work rules, which often translate into wage issues (pp. 335ff.). Most curiously, the activities of employers do not count for much in their account of industrial conflict. On the economic climate at the turn of the decade see Caron, "Dynamismes et freinages", loc. cit. 
Rousseau's projet de loi as a legal trap - an early draft required registration of the names of all the members of the union - and as an attempt to co-opt workers into the politics of mutual aid advocated by the ideologues of solidarité, the measure passed in parliament. Waldeck-Rousseau, an industrialists' lawyer, hoped the new measure would structure peaceable and orderly relations between labor and capital. ${ }^{31}$

In 1884, too, the Opportunists launched an enquête on the causes of the economic crisis. In the pattern of responses we may clearly discern the lineup of freetraders against protectionists, not simply according to industry and region, as one could expect, but also according to the intensity, or lack thereof, of industrial conflict. The commercial leaders of Bordeaux, for example, saw no need to interfere with trade, nor do anything in behalf of the workers, who had not disturbed their social peace. ${ }^{32}$

The chambers of commerce of Saint-Quentin and of Nancy, both industrial cities (Saint-Quentin largely a textile-manufacturing city), demanded help. The chamber of commerce of Chalon-sur-Saône, Autun and Louhans, towns situated in a region of fine-wine production but also the home of the great Schneider-owned Le Creusot works, was well-situated to re-state the article of faith - admittedly largely true - of French protectionists: that the best means of improving the lot of industry and commerce would be to take measures to benefit French agriculture, "the principal source of profits in our region". 33

But the most revealing written response to the inquiry came from the business spokesmen of the great metallurgical and textile-producing center in the North, Lille. The authors of the return from Lille complained, above all, that other nations' industrialists had both tariffs to hide behind and the services of a relatively cheap labor-force. Because French workers' wages, "the principal component of cost", had risen in the past few years and because of the wretched effects of "strike upon strike", foreign customers could depend neither on the stability of French prices nor on promised

${ }^{31}$ E. Dolléans, Histoire du mouvement ouvrier (3 vols; Paris 1936-53), II, pp. 25-26.

32 The réponse of the Bordeaux merchants denied that workers were suffering any important new difficulties. They were about as well-off, asserted the Bordeaux return, as they had been twenty or twenty-five years before. Bad harvests, which could have sent bread prices up, had been compensated for by the temporary admission of foreign-grown wheat. Moreover, the optimistic statement concluded with a dig at the cotton manufacturers, increases in the scale of production in recent years had reduced clothing prices, which had held down increases in the cost of living. Enquête parlementaire sur la crise économique et sur la situation industrielle, commerciale et agricole en France, 1884, Réponse Bordeaux, Archives Nationales C 3329.

${ }^{33}$ Réponse Chalon-sur-Saône, Autun, Louhans, ibid. 
delivery dates. Only "foreign competitors [ . . . profited" from the pay gains French workers exacted in strikes. There followed a long diatribe against, in turn, workers' organizations, both for turning the workers against their employers and against capital in general, and for their efforts to reduce the length of the workday, which only hurt production without benefitting labor. And, finally, the Lille chamber of commerce complained about the high taxes which weighed so heavily upon the industrialists of the Nord. The workers would have to work harder and more intelligently, concluded the Lille analysis of the depression; and they should not allow themselves to be misled by "outside agitators". ${ }^{34}$

The views expressed by the Lille manufacturers make manifest a bedrock belief widespread among the protectionist industrialists: that profits, wages and foreign competition were linked in a triangle of forces. Foreign competition reduced profits, which in turn drove down wages. Conversely, reduced foreign imports permitted higher profits, which allowed wage improvements. But wages, i.e. labor, stood at the pinnacle of the production triangle. Practical men, they operated with a rough-and-ready Ricardianism. Wages, they claimed, were their principal cost of production. The vise squeezing their profit margins - squeezing their family's patrimony had as one jaw, their wage bill, the other, foreign competition. The debateat-distance between the socialist Paul Brousse and Senator Nicolas Claude, one of the founders of the AIF, in their testimony at the hearings of the enquête demonstrates this point rather graphically.

On March 8th Paul Brousse, speaking in behalf of the Fédération des Travailleurs Socialistes de France, the so-called Possibilists, appeared before the Commission to argue that the wages of French workmen were not the cause of the economic crisis, as so often had been alleged. Rather, he reminded the members of the Commission the reason that French textiles could not compete in world markets lay in the high domestic costs of coal, machinery and labor. Apparently unable or unwilling to do anything about the first two costs, he charged, French capitalists had decided to make the wages of their workers "the great battlefield". "They claim that French workers are better paid than workers in other lands, and that as a result it is not possible to hold out against the foreign competition." If French workers were paid well, he asserted, it was because they were more productive than workers elsewhere.

A few weeks later the thread-and-cloth manufacturer Senator Nicolas Claude from Saulxures in the Vosges, a few kilometers down the road

34 Réponse Lille, pp. 6-10, ibid. 
from Méline's home in Remiremont, appeared before the Commission to challenge Brousse's testimony and, in so doing, to articulate in succinct fashion the position of most protectionist industrialists for the coming decades. Claude, like the spokesmen of the chambers of commerce of Chalon-sur-Saône, Autun and Louhans, saw that the French agricultural crisis lay at the center of the general economic crisis, and that "from the difficulties of agriculture flowed, in part, those of industry". What of the problems originating in the industrial sector? To be sure something had to be done about the high price of domestic coal, as well as high internal transportation costs, he argued. And especially, the Senator emphasized, "the fact of the inflation of wages" had to be confronted. To that purpose, he concluded, "We must bring about a good understanding between labor and capital, that is, we must arrive at the elimination of the strikes, which cripple our production to the profit of that of other nations." 35

The rate and intensity of labor conflict slowed between 1885 and 1890. An observer inclined to optimistic judgments might have hypothesized that the tariff and the syndicat law of 1884 were beginning to effect Claude's hopedfor "good understanding between labor and capital". Although the steep decline of both industrial and agricultural prices had halted, they remained in a deep depressionary trough. And agricultural prices rested five index points below the levels for industry. The agriculture interest needed attention; its recovery would aid that of industry. But, in addition, no responsible political leader could depend on the continuation of industrial peace in planning for the future. The suffering growers had to be mobilized against the freetraders in the Chamber. United, the leaders of national industry and national agriculture could raise the tariff wall still higher. That measure might also serve to protect them from the discontent and anger of a class of workers still in its germinating state.

However, as the end of the century approached, labor disputes increased and grew more fierce. ${ }^{36}$ It is important to recognize that these were not strikes of the radicalized and volatile construction workers and skilled artisans, who had in the past played a large role in Parisian labor unrest. These were modern industrial strikes overwhelmingly, centered in the area of the Nord and the Pas-de-Calais involving the textile workers and miners of Northern France. Metal workers were not far behind. "The proletariat of the large factory now occup[ied] center stage; they act[ed] no

${ }^{35}$ Procès-verbaux, séance du 1 avril 1884, pp. 141-50; séance du 8 mai, p. 343, ibid.

${ }_{36}$ Tilly and Shorter, Strikes in France, Appendix B, pp. 260ff.; Perrot, Les Ouvriers en grève, I, pp. 96-97. 
longer simply to protect themselves, but to attack; they [were] organizing", writes Michelle Perrot. ${ }^{37}$

When in 1890-91 the Conseil Supérieur du Commerce et de l'Industrie undertook its own inquiry on whether France should increase or decrease its external commerce, the problem of labor came up repeatedly in the answers of affected industrial centers. The regions of AIF strength wanted both labor peace and tariffs. ${ }^{38}$ The defeat of Boulanger in 1889 lifted the moderate republicans' fear of the Right. Clearly, socialism now provided a common enemy for defenders of the existing order ${ }^{39}$ Le Travail National well understood the benefits of the incipient rapprochement between the conservative liberals and the monarchist Right: "A certain spirit of reconciliation animates all the members of the Chamber. We hear today in the meetings in which members of the Right hold the majority, the same language as we heard yesterday at one attended almost exclusively by republicans." 40

Outside the Chamber the AIF mobilized its members and allies for the forthcoming struggles for a new tariff. Representatives of the Comite des Forges, the Comité Central des Houillères, the Chambre syndicale des

${ }^{37}$ Perrot, Les Ouvriers en grève, 1, pp. 96, 118. For 1889-90 Paris was the site of only 7\% and $3 \%$ of the strikes. In $188959 \%$ of the strikers were textile workers largely from the North; in $189035 \%$ of the strikes and $53 \%$ of the strikers were involved in textile production.

38 The chamber of commerce of Roubaix, the textile center, criticized the damaging consequences of the treaties and went on then to inculpate for their commercial difficulties "the low price of labor in Germany". The chamber of neighboring Tourcoing urged that, because competition of neighboring nations threatened, it was "high time to safeguard our national industries and the pay of our workers by means of compensatory duties". The cotton manufacturers of the Vosges, especially of the town of Epinal, offered as general causes for the difficulties of their industry "foreign competition, the rise in labor costs, finally, and especially, overproduction". The chamber of commerce of Albi blamed primarily "the strikes of the coal basins, which have increased the price of coal and, as a result, of other products employing coal in their manufacture". The chamber of Valenciennes advocated non-renewal of the treaties and raised duties on coal and coke. The iron manufacturers of the Jura complained of the German competition, the American, Italian, Spanish and Russian iron tariffs, and especially of the decline in orders with the completion of French rearmament and the slowing of railroad construction. Although the majority of the responses, some one hundred and fifty, did not focus on the question of labor - like those of the chambers of the Jura and of Valenciennes those that did were sent from regions of strike-ridden industries; their members were militant supporters of Méline's AIF and of new tariffs. The responses may be found in Réponse au questionnaire du Conseil supérieur du commerce et de l'industrie sur le renouvellement des traités de commerce, 1890-91, Archives Nationales F 126418 and 6916.

${ }^{39}$ R. D. Anderson, France, 1870-1914. Politics and Society (London, Henley, Boston, 1977), pp. 14-15.

40 Le Travail National, 1 December 1889 , p. 564. 
Fabricants de Sucre, the Société des Agriculteurs (to name the important participants) appeared under the auspices of the AIF at a great unity meeting held in Paris on 17 December 1890. It closed with a resolution against the calumnies of "persons who, for the most part, have neither factories, nor lands, nor workers depending on them", and the affirmation that the protectionists sought nothing more than to protect "national labor". +1

The debates on the tariffs began in the Chamber at the end of April 1891. As May 1st approached, government and industrialist circles grew apprehensive. They remembered the last May 1st, the first French May Day, and the demonstrations and parades of that day in Paris, Marseille, Bordeaux and Lyon, the free-trade strongholds. They also had witnessed the explosion of working-class militancy in Lille, Roubaix, Tourcoing, SaintQuentin, Calais, Sète, Roanne, "in the mines, the textiles of the Nord and the Massif Central". ${ }^{42}$ Choosing to see the upcoming May Day as potentially insurrectionary, the Opportunist government moved troops to or near important industrial centers.

In the Nord workers of the little (16,000 inhabitants) wool-textile town of Fourmies took the day off to celebrate the workers' holiday. A confrontation developed with the troops arrayed before the Hôtel de Ville, who fired into a crowd of men, women and children, killing nine (eight of them children) and wounding thirty. The Minister of the Interior in the Freycinet government, Ernest Constans, tried to place the blame on socialist agitators. He had Paul Lafargue, a leader of the growing Parti Ouvrier, indicted for inciting to murder and pillage. Lafargue had spoken in the North the month before the massacre and had returned again in July to win more adherents to socialism in the wake of the shootings. Culine, the party's secretary in Fourmies, was also indicted. The government readily obtained a conviction of the two socialist agitators. As socialist leaders were being sent off to prison for a government-caused blood-letting, the Chamber majority worked out the details of the new tariff. Méline worked for passage actively behind the scene and from the rostrum of the Chamber.

Less than two weeks after the Fourmies shooting, with news of the trial of Lafargue and Culine filling the newspapers, Méline seized a moment in the deliberations on the tariff to address himself to the causes of, and remedies for, socialism. Although it was true that socialism "raged" in neighboring Germany, he asserted, it was even more menacing in France because "in this land of libre échange wages are of necessity lower than they are in

${ }^{41}$ Ibid., 21 and 28 December 1890, pp. 633-56.

42 D. Ligou, Histoire du socialisme en France (1871-1961) (Paris, 1962), p. 114. 
Germany". "I realize", he admitted, that the movement of socialism results from causes much more profound than the commercial policy of a country. It is fed,

in my opinion, from the very legitimate desire of the disinherited classes to improve their situation [. . .]. [We] must concern ourselves ceaselessly with the questions that these aspirations engender.

I believe [ . . ] that the best form of socialism - I do not shrink back form the word - would be that of providing work for our workers, of improving their conditions and, to the degree possible, of raising their wages and improving their welfare. ${ }^{43}$

The socialists responded sharply. Writing in the August issue of La Revue Socialiste, Adrien Veber charged Méline and the rest of the tariff commission of the Chamber with using the tariffs as "a weapon of civil war and perhaps of external war as well". Their work would only re-impose the "reactionary yoke" on France, and solidify "the privileges of the soil and of industrial monopoly". ${ }^{44}$

When a Radical deputy from Lille died in September, the POF, led in the North by the astute Gustave Delory, decided on the strategem of nominating Lafargue for the seat in this heavily working-class district. While the protectionists in the Chamber ironed out their final disagreements about the provisions of the pending tariff, ${ }^{45}$ Lafargue sent speeches from prison to the electors of the district and the entire country hammering home his attack on the Opportunist government as "murderers of the workers, starvers of the workers".

He won the seat and the authorities, forced to honor his parliamentary immunity, released him from prison. He triumphantly toured the industrial North that fall and winter, speaking everywhere against the tariff. But neither his speeches nor their echoes heard at the National Congress of the POF at Lyon in November could halt the passage of the tariff. By the end of December it had passed both the Chamber of Deputies and the Senate by large majorities. The new tariff law, wrote Auguste Michel in Le Travail National, "is, on the whole, what we wanted from the beginning, what we have never ceased to hope for and to back". ${ }^{46}$

43 Journal Officiel, Chambre des Députés, 12 May 1891, p. 867.

4 A. Veber, "Réaction et protection", in: Revue Socialiste, XIV (1891), esp. p. 145.

45 Smith, Tariff Reform, pp. 203ff., gives the details of the delicate bargaining.

t6 Le Travail National, 17 January 1892 , p. 29. A text of the new tariff is reprinted on p. 34. Although there had to be bargaining among the various interests seeking advantages, my reading of the sources does not confirm Smith's emphasis on the exclusive role of the tariffs in the creation of ruling-class collaboration. Class alliances are not worked out over the duties on low-numbered cotton threads. Classes fear not things, but other 
But the jubilation of the protectionists over their new tariff was tempered immediately. While still under indictment for high crimes, a gifted and energetic spokesman for social revolution had been elected to a seat in the Chamber. As the Progrès du Nord, newspaper of the Lille textile interests, interpreted the election of the first Marxist deputy, "M. Lafargue elected from Lille. That means agitation en permanence in the factories and the workshops." ${ }^{47}$ On assuming his seat Lafargue justified the protectionists' apprehensions by calling for the immediate abrogation of all duties on food products. ${ }^{48}$ In a pamphlet of the same year he denounced the government as one of the classe possédante, which had passed a tariff which would "burden foodstuff to the value of a billion francs a year [. . .] for the sole purpose of elevating ground rents". 49

But Lafargue at that moment spoke only for a small, if growing, party. The Opportunists might justly have put his electoral success down as a fluke, if socialists, running in the May elections of 1892 , had not won majorities in the municipal governments of Roubaix, Marseille, Narbonne, Montluçon, Commentry, Toulon, to name just the major victories. Socialist minorities won seats in Calais, Montpellier, Saint-Nazaire, Darnetal and Wattrelos. Throughout France, but especially in the iron-working and textile North, they won places on the conseils généraux and the conseils d'arrondissement. Clearly a social pacifier - like the appeal to national labor of the new tariff - was much needed. It was clear, too, that any such pacification would neither develop quickly nor automatically.

The year 1893 brought vindication for those who wished to take measures which would bring social peace to the Republic. In that year both the need for the tariff and the agonizingly slow workings of a tariff policy conceived as a social policy were demonstrated. An accelerating tempo of strikes in 1893 dampened the post-passage optimism of the tariff-coalition partners. In 189245,900 workers participated in 268 strikes. By the end of 1893

classes. Smith's treatment leaves out the larger socio-political issues - and the working class.

47 For the story of Fourmies and the socialist breakthrough in its wake, see C. Willard, La Fusillade de Fourmies (Paris, 1957), pp. 77-78 and passim; Baker, "A Regional Study of Working-Class Organization in France", op. cit., pp. 64ff.; Ligou, Histoire du socialisme en France, op. cit, , pp. 11ff.; J. Hilsheimer, "Interessengruppen und Zollpolitik in Frankreich: Die Auseinandersetzungen um die Aufstellung des Zolltarifs von 1892" (Inauguraldissertation, Heidelberg, 1973), pp. 426-27; and more for the feel of the moment than for information on the election see Laura Lafargue to Friedrich Engels, 22 November 1891, in F. Engels, P. and L. Lafargue, Correspondance, ed. by E. Bottigelli (Paris, 1956-59), III, pp. 132-33 and passim.

48 Le Travail National, 21 February 1892.

49 P. Lafargue, Le Communisme et l'évolution économique (Lille, 1892), pp. 22-23. 
France had experienced 634 labor conflicts involving 172,500 employees. Once again the militancy of the industrial textile workers put them in the forefront ${ }^{50}$ Perhaps the most disquieting labor problem of 1893 - beyond the clear signs that an industrial working class in the modern sense was coming of age - was the proliferation of labor radicalism to the land, as manifested in the strikes of the half-peasant, half-worker woodcutters of the Cher and the Nièvre.

When the results of the parliamentary elections of August-September 1893 revealed that forty-nine socialist deputies had "penetrated into the Chamber", to use Méline's alarmed word, industrial and agrarian social conservatives discovered yet another font of danger. Among the forty-nine was Jaurès, who was elected as a socialist in the second electoral district of Albi by the combined votes of miners and small peasants. He won by creating on the bottom of society the kind of union which had been created by the pro-tariff coalition at the top - in part by the men he had defeated. ${ }^{51}$

Were the protectionists correct to believe tariffs to be suitable instruments to achieve the twin goals of industrial pacification and ruling-class unity in the late nineteenth century? In the 1880's and 1890's they were hemmed in by powerful competitors and crippled by the collapse of domestic purchasing power. They lacked a well-developed colonial market. Thus they despaired of ending the business depression through expansion of sales. Domestically, efforts to increase worker productivity by means of capital investments, speed-ups, increased labor discipline, paternalism and send-

${ }^{50}$ In March the Saint-Quentin lacemakers walked out; in April and May the dyers, cotton spinners and garment workers of Amiens; in May, too, the dyers of Roubaix; and in August the wool spinners of Vienne. Although all over France there were strikes of skilled construction workers - carpenters, joiners and cabinet makers -, more significant were the walkouts of the mécaniciens-constructeurs of Nantes, métallurgistes of the Rivede-Gier, and the thousands of miners of Béthune. Ligou, Histoire du socialisme en France, p. 117.

51 His election posed a serious threat to the class allies who had united industrial wealth and agricultural wealth around means of protecting the social order. To win election from the district Jaurès had had to defeat both the Marquis de Solages, the incumbent, a director of the Mines de Carmaux and a rallié, and his father-in-law and the local political boss, Baron René Reille, also a rallié, chairman of the Mines and, until his death in 1898 , head of the Comité des Forges. Both men were active members of the AIF. Reille served on the governing council until his death; he had precipitated a bitter eighty-day strike in August 1892 when he fired Jean-Baptiste Calvignac, an official of the miners' union, on the occasion of Calvignac's election as Mayor of Carmaux. It was in the wake of the successful struggle to have him re-instated to his job in the mines, followed by the resignation from his deputy's seat of the humiliated Solages, that Jaurès, running as a socialist, won election to the Chamber. Le Travail National, 18-25 June 1893. 
ing for the army had too often broken on the rocks of workers' resistance. The desperate industrialists of Roubaix even re-introduced child labor late in the century. ${ }^{52}$

Tariffs promised to stabilize existing industries, increase prices and profits, and permit concessions to pacify the growing militancy of the new class of industrial workers of the provinces. Accordingly they offered an ideal economic solution to the ever-more insistently raised social question. Having no reforms to offer,$^{53}$ the industrialists offered their workers safe jobs and steady pay to insure the fragile social order of their new Republic. They offered as well the illusion of agrarian protection to the stricken peasants. Moreover, that same policy invited large growers to join a socially conservative alliance at a particularly precarious moment of economic development. And as an added, if perhaps unplanned, benefit the tariffs which held forth promise of protecting both their grains and industrial goods might set peasant producers against industrial workers over the raising cost of workers' bread and peasants' manufactured needs. Finally taking into account the business ledgers of both industrialists and of the large growers - urban workers, the multitude of peasant consumers and the native inhabitants of the colonies would pay for any increases in what they received with higher prices for what they had to purchase. Tariff policy in France, therefore, was social policy. Yet, it was not simply a negative social conservatism; rather, it was a far-sighted look backward.

Did the tariffs of 1882 and 1892 hold back the proliferation of Jaurès's sort of agricultural-industrial alliance? Or failing that, did they facilitate the fashioning by the protectionist allies of bulwarks against the domestic enemies of national labor to complete the system of defenses begun with the tariffs? The answer to these worrisome questions only became clear in the decades that followed. However, we must count the willingness of socialist leaders to sit together with Jules Méline in the government of the Union Sacreé in 1914 as evidence of the success of the ideology of national labor, a success that lasted at least to 1936 .

${ }^{52}$ D. Landes, "Religion and Enterprise: The Case of the French Textile Industry", in: Enterprise and Entrepreneurs in Nineteenth and Twentieth Century France, ed. by E. C. Carter, II, et al. (Baltimore, London, 1976).

${ }^{53}$ See newly the study on the causes for the lack of social reform in the early decades of the Third Republic by J. F. Stone, The Search for Social Peace: Reform Legislation in France, 1890-1914 (Albany, N.Y., 1985). 